\title{
Getting the work done: motivation needs and processes for seafarers and dock workers
}

\author{
Kyriaki Mitroussi • Theo Notteboom
}

Received: 29 August 2013 / Accepted: 23 April 2014 / Published online: 8 May 2014

(C) World Maritime University 2014

\begin{abstract}
Most of current literature on motivation at work is acontextual neglecting the role of contextual layers found in distinct industries or professional environments. The aim of the present paper is to extend traditional notions of work motivation by considering more explicitly the importance and impact of professional/industry contexts and extant processes in them on work motivation. The focus of the paper is on two maritime-related professional environments: seafarers working on board merchant vessels and dock workers performing cargo handling operations in seaports. The paper critically reviews the context and constituents of the two professions in view of adding a dimension/layer of industry context and environment to mainstream literature on motivation.
\end{abstract}

Keywords Motivation · Seafarers · Dock labor · Employment · Human resources

\section{Introduction}

Effective human resource management has been positively associated with higher employee productivity and better financial results (Delaney and Huselid 1996; Huselid et al. 1997) as well as with sustaining competitive advantage (Pfeffer 1995). Motivation of employees is central to effective human resource management. However, traditional notions of work motivation do not explicitly consider the importance and

\footnotetext{
K. Mitroussi

Logistics and Operations Management, Cardiff Business School, Aberconway Building, Colum Drive, Cardiff CF10 3EU Wales, UK

e-mail: MitroussiK@cardiff.ac.uk

T. Notteboom $(\bowtie)$

Institute of Transport \& Maritime Management Antwerp (ITMMA), University of Antwerp, Kipdorp 59, 2000 Antwerp, Belgium

e-mail: theo.notteboom@ua.ac.be

T. Notteboom

Antwerp Maritime Academy, Antwerp, Belgium
} 
impact of professional/industry contexts and extant processes in them on work motivation. In view of filling this gap in existing literature, this paper explores motivation for seafarers and dock workers as constructed by the impact of contextual layers specific to their profession and the shipping industry. The port and shipping industry is an under-examined industry per se in respect of motivation issues (see, for example, Mitroussi and Chang 2008; Thomas et al. 2003; V.Group 2006). More recently, the global maritime community has started paying increased attention to employee-related matters. For example, the Maritime Labour Convention (MLC), 2006 is the new global regulatory instrument providing comprehensive rights and protection at work for the seafarers at a global level. It is the result of tripartite negotiations considering both seafarers and shipowners interests and consolidating dozens of ILO standards adopted since the 1920s and it is due to take effect in August 2013. Although there is ongoing debate regarding the effective implementation of the MLC 2006 once it enters into force (Piniella et al. 2013), there is widespread belief that the convention will be effective in protecting the seafarers (Bolle 2006).

However, despite such important regulatory developments, much greater and more diverse consideration of employee-related matters is needed in the wider maritime sector in order to both create satisfied employees and secure positive work outcomes for employing entities in the sector. This paper critically reviews the context and constituents of the two professions of seafarers and dock workers in view of adding a dimension of industry context and environment to mainstream literature on motivation and performance.

The central research question is as follows: are motivation tools used for the seafarer and dock work professions atypical due to the very specific industry context and environment. In order to answer the research question, we first provide a literature review on motivation. Then, an in-depth analysis is given of the job characteristics along a number of internal and external forces to the professions which encapsulate the distinctive nature of the working environment on ships and at cargo handling facilities in seaports. The fourth section presents a critical discussion of the range of tools available to motivate existing seafarers and dock workers and to motivate others to join these professions. The concluding section considers the extent to which the specific industry contexts in seafaring and dock labor instigate a mix of motivation processes tools that is distinct from other industries. Based on the analysis, the paper proposes the addition of a contextual layer to the study of motivation at work and explores avenues for further research.

\section{Literature review on motivation}

Motivation at work has attracted psychologists, economists, and sociologists (Vroom 1964) in order to explain or direct behavior and actions for improved performance in organizations. Simpson (1983) points to a number of signs of motivation, such as high energy and performance and willingness to cooperate, accept change and assume responsibility. Lack of motivation can result in apathetic work attitude, poor timekeeping and high absenteeism, poor industrial relations, and obstinacy to change. Reward systems consistent with motivational concepts have a positive impact on recruitment and retention, corporate culture, and even labor costs (Lawler 2000) while 
they have also been connected with higher levels of perceived organizational performance (Allen and Helms 2002).

A variety of factors explain variations to the degree of employees' motivation, ranging from innate needs and cognitive processes to external/environmental influences (Hume 1995), such as the attempt to meet unfulfilled, innate needs, prioritized on an ascending scale - i.e. physiological, safety, social, esteem, and self-actualisation needs (Maslow 1954; Alderfer 1972) and conscious expectations that particular actions will lead to particular, desirable results (Vroom 1964). Managers can also try to instill the need of achievement, the need for power and the need for affiliation in their employees as these trigger human behavior (McClelland 1962). For example, the need for achievement has been linked with successful entrepreneurial activity (McClelland and Winter 1969; Miner et al. 1994). People's objectives and personal targets (Locke 1968) as well as the feeling of fair or equitable return for efforts (Adams 1963, 1965) have also been thought to play important role in determining behavior with regard to motivation.

Managers must ensure the existence of an adequate job context of working conditions - i.e. salary, company policies, interpersonal relations, and supervision - to avoid employee dissatisfaction, but employee motivation is effected with challenging jobs and opportunities for advancement and recognition (Herzberg et al. 1959), participative management, responsibility and good interpersonal relations (McGregor 1960). Five job elements, namely, skill variety, task identity, task significance, autonomy, and feedback, have particularly been found that, when combined, create internal rewards to individuals and create motivation. This is because they contribute to making employees experience the meaningfulness and responsibility of their job and becoming aware of the progress they make in them (Hackman and Oldham 1976, 1980). Warr (2002) expanded the list of job characteristics which can act as predictor variables for job satisfaction to include, among others, physical security, supportive supervision/ effective leadership, opportunity for interpersonal contact, environmental clarity and the wider social position of the job.

A variety of work-related variables have been examined in the motivation literature underlining the interplay between extrinsic motivators - e.g., remuneration which allows the individual to obtain outcomes of value - and intrinsic motivators - e.g., satisfaction which comes from the experience of successful activity performance (Deci and Ryan 1985). Thakor and Joshi (2005) have found that the two motivators, the extrinsic motivator (namely, pay satisfaction) and the intrinsic motivator (namely, experienced meaningfulness) are complementary to each other. They have further suggested that organizational identification has a positive motivating impact, too. Aroused perceptions of employees about their jobs can increase in the short-term job satisfaction (Wong et al. 1998). Other employment factors found to be important in employee motivation include: the effect of performance control systems on motivation techniques (Miao et al. 2007); the role of quality relationships at work and of equitable contract conditions (Rose and Manley 2010); the commitment of the organization to the employee and the commitment of the employee to the organization as well as the impact of other relationships - e.g., with the supervisor-and of employee work attitudes - e.g., degree of competitiveness (Grugulis and Bevitt 2002; Murphy 2004).

More recent papers in the area of occupational health studies focus on the role of contextual levels of work environment factors. For example, Labriola et al. (2006) 
concluded that both the psychosocial and physical work environment are important predictors of return to work after sickness. Examples of negative work environment factors include workplace bullying (Ortega et al. 2011), negative consequences of changes, poor leadership, poor social support and high physical and mental demands at work compared to the individual's capacity (see also Josephson et al. 2008).

Although motivation has been examined in various business settings (Zinkhan et al. 1990; Grugulis and Bevitt 2002; Horwitz et al. 2003; Miao et al. 2007; Murphy 2004; Rose and Manley 2010), research agendas have failed to include investigation of sector-specific components which may shape-individually or collectively-employees' motivation and may affect the relativity and suitability of tools for instigation of work motivation. As such, most of current literature is acontextual neglecting the role of contextual dimensions found in distinct industries or professions. Limited research in employee motivation in the context of specific industry and/or professional constituents leaves the field under-theorized and raises questions of insightfulness regarding the successful applicability of different motivation techniques in different working environments.

\section{Context and constituents of the professions of seafarer and dock worker}

In this section, we analyze the distinctive nature of the working environment on ships and at cargo handling facilities in seaports in view of identifying job characteristics along a number of internal and external forces to the professions. The main job characteristics are summarized in Table 1 and grouped according to three dimensions: market conditions and required skills, social conditions and structures and working conditions.

The seafarer and dock labor employment environments share a lot of common features distinctive from other industries, such as the masculinity of the professions, social structures/control based on gangs or crews, rapid change of the nature of work to increasingly high skilled and technical in need for continuous training and exposure to harsh and or dangerous working circumstances. Still, the seafarer and dock worker environments are not entirely the same given noticeable differences in terms of the multicultural nature of the workforce, the social aspects related to the time spent away from family, the role of labor unions, employee turnover and the existence of international standards guiding the profession. There are also significant cultural differences leading to significant variation in interpersonal contact and wider social positions of each job in various parts of the world. The following sections provide a more in-depth discussion.

\subsection{Market conditions and required skills}

The rise of specialized terminal equipment (e.g., specialized quay and gantry cranes, forklifts, terminal tractors, straddle carriers, reach stackers, etc.) and specialized ships (e.g., container ships) increased the need for skilled and qualified dock workers and seafarers. This trend was further reinforced by a stricter regulatory environment and the introduction of advanced information technology.

The demand for high-skilled dock workers has reinforced inter-company competition for attracting the best dockers. In shipping, a boosted world trade and demand for 
Table 1 Job characteristics along a number of dimensions

\begin{tabular}{|c|c|c|c|}
\hline Characteristics & Seafarers & Dock workers & (Dis) Similarities \\
\hline \multicolumn{4}{|c|}{ Market conditions and required skills } \\
\hline $\begin{array}{llll}\begin{array}{l}\text { Fluctuation level in labor } \\
\text { demand }\end{array} & & & \\
\end{array}$ & $\begin{array}{l}\text { High labour demand at } \\
\text { international level - high } \\
\text { fluctuation in labour demand at } \\
\text { national and company level }\end{array}$ & $\begin{array}{l}\text { High due to peaks in ship arrival } \\
\text { patterns, seasonality, economic } \\
\text { cycles. }\end{array}$ & \\
\hline $\begin{array}{l}\text { Easiness to fill job vacancies } \\
\text { Inter-company competition for } \\
\text { attracting skilled personnel }\end{array}$ & $\begin{array}{l}\text { Dependent on job specification } \\
\text { and on ship type (i.e. difficult } \\
\text { for specialized carriers, e.g. } \\
\text { LNG) } \\
\text { Inter-company competition is } \\
\text { high, especially for certain } \\
\text { specializations and / or for shore } \\
\text { ex-seafarers' placements }\end{array}$ & $\begin{array}{l}\text { Dependent on job qualifications } \\
\text { needed and on terminal type } \\
\text { (e.g. difficult for container } \\
\text { terminals). } \\
\text { Inter-company competition is } \\
\text { moderate in case of dock labour } \\
\text { 'pools' (casual work). High in } \\
\text { case of fixed/permanent } \\
\text { personnel. }\end{array}$ & \\
\hline Change of the nature of work & $\begin{array}{l}\text { Increasingly high skilled and } \\
\text { technical in need for continuous } \\
\text { training }\end{array}$ & $\begin{array}{l}\text { Increasingly high skilled and } \\
\text { technical in need for continuous } \\
\text { training }\end{array}$ & \\
\hline Basic technical skills needed & $\begin{array}{l}\text { Related to job post onboard and } \\
\text { ship type }\end{array}$ & $\begin{array}{l}\text { Related to specificity of } \\
\text { handling equipment. }\end{array}$ & \\
\hline $\begin{array}{l}\text { International standards guiding } \\
\text { the profession }\end{array}$ & $\begin{array}{l}\text { Specific international regulatory } \\
\text { framework (e.g. by ILO, IMO) - } \\
\text { varying national implementation }\end{array}$ & $\begin{array}{l}\text { Some role for International } \\
\text { Labour Organization (ILO), but } \\
\text { standards mostly set at local/port } \\
\text { level. }\end{array}$ & \\
\hline \multicolumn{4}{|c|}{ Social conditions and structures } \\
\hline Gender mix & $\begin{array}{l}\text { Low. Only very small } \\
\text { participation of women as deck } \\
\text { officers. }\end{array}$ & $\begin{array}{l}\text { Very low. Women only found as } \\
\text { logistics workers in some ports } \\
\text { (i.e. light work such as fruit } \\
\text { sorting, quality control, etc.) }\end{array}$ & \\
\hline Role of labor unions & $\begin{array}{l}\text { Variable (e.g. depending on } \\
\text { whether seafarers come from a } \\
\text { traditional or not shipping } \\
\text { nation) but generally } \\
\text { increasingly lower - ITF }\end{array}$ & $\begin{array}{l}\text { Strong to very strong. Union } \\
\text { membership is often an informal } \\
\text { prerequisite to job access. }\end{array}$ & \\
\hline $\begin{array}{l}\text { Group structure at the level of } \\
\text { the profession }\end{array}$ & $\begin{array}{l}\text { High agency employment - a } \\
\text { 'project type' of work by a small } \\
\text { group of people }\end{array}$ & $\begin{array}{l}\text { Dock worker 'pools' are quite } \\
\text { common given typical casual } \\
\text { nature of dock work. }\end{array}$ & \\
\hline $\begin{array}{l}\text { Group structure/formation on the } \\
\text { work floor }\end{array}$ & $\begin{array}{l}\text { Distinction between officers and } \\
\text { lower crew. } \\
\text { Distinction between deck and } \\
\text { engine. }\end{array}$ & $\begin{array}{l}\text { Gangs led by 'foremen'. } \\
\text { Deployment of multiple gangs } \\
\text { for handling of one ship. }\end{array}$ & \\
\hline $\begin{array}{l}\text { Multicultural nature of the } \\
\text { workforce }\end{array}$ & $\begin{array}{l}\text { High with impact on } \\
\text { communication, working and } \\
\text { living conditions on board. }\end{array}$ & $\begin{array}{l}\text { Low, particularly in cases of } \\
\text { closed-shop or highly-unionized } \\
\text { labor pools. }\end{array}$ & \\
\hline Employee turnover & $\begin{array}{l}\text { High turnover onboard (with } \\
\text { impact on social life, training, } \\
\text { employment succession and } \\
\text { retention, job performance). }\end{array}$ & $\begin{array}{l}\text { Low for permanent employment } \\
\text { dock work structure. 'Gangs' } \\
\text { tend to be rather constant in } \\
\text { composition. Causal workers in } \\
\text { pool systems might change } \\
\text { terminal regularly but stay in the } \\
\text { same port environment. }\end{array}$ & \\
\hline \multicolumn{4}{|l|}{ Working conditions } \\
\hline Time spent away from family & $\begin{array}{l}\text { Long periods of time away from } \\
\text { family }\end{array}$ & $\begin{array}{l}\text { Limited to duration of shift. } \\
\text { Night and weekend work are } \\
\text { common. }\end{array}$ & $\neq$ \\
\hline $\begin{array}{lll}\text { Safety } & \text { record/perception on } \\
\text { safety } & & \end{array}$ & $\begin{array}{l}\text { Considered as a dangerous } \\
\text { profession - Psychological } \\
\text { stresses - Security / Piracy }\end{array}$ & $\begin{array}{l}\text { Considered as a dangerous } \\
\text { profession. }\end{array}$ & \\
\hline $\begin{array}{l}\text { Exposure to harsh working } \\
\text { conditions }\end{array}$ & $\begin{array}{l}\text { Perils of the sea, weather, } \\
\text { temperature differences, use of } \\
\text { heavy equipment, culture of long } \\
\text { hours of work, fatigue }\end{array}$ & $\begin{array}{l}\text { Weather, } \\
\text { differences, use of heavy } \\
\text { equipment. }\end{array}$ & \\
\hline
\end{tabular}

green equality sign "job characteristic is very similar between dock workers and seafarers"; red inequality sign "job characteristic is very different"; yellow solid line "job characteristic is somehow similar"

Source: own elaboration

sea transport has brought increases in the size of the world merchant fleet and subsequent increased human resource requirements. At the same time, the contemporary unattractiveness of the seafaring occupation - primarily due to the availability of shore alternatives (Wu and Sampson 2005), a high demand of specialized skills and 
qualifications, a declining number of graduates from marine academies (McConville and Glen 1997; Guo et al. 2006), and an aging workforce, particularly officers (Wu and Morris 2006), created a demand/supply gap in seafarers with an expected 83,900 global shortfall of officers (IMO 2009). Extensive flagging-out has made the supply market for seafarers a single global labor market and brings increased fluctuations in seafarer labor demand at national level. At a company level, cyclicality and severe freight market swings and companies' own strategic orientations in response to them also affect labor demand. Fleet expansion plans, fleet replacement policies, entry into new shipping markets, diversification in other non-shipping related sectors, potential mergers or acquisitions or the use of third party ship managers for a ship owner's vessels, they all have an impact on both the number of employees needed in the future and their qualifications.

Shipping companies compete with each other for quality and competitive workforce. There is a high cost for hiring the wrong employee, around $\$ 5,000$ in lost productivity and training, with higher costs incurred for managing positions (Fernandez-Araoz 1999), or in the case of wrong recruitment decisions in the shipping industry of great externalities. With many ex-seafarers constituting a source of skilled shore labor (Pettit et al. 2005), inter-company competition for skilled personnel is intensified. Shipping companies may have to adjust their human resource management strategies, resort to the use of marketing tools and portray themselves as employers of choice, if they are to successfully compete and attract the much sought-after, scarce-qualified shipping expertise (Kokoszko and Cahoon 2007). Performance of governments with respect to regulation enforcement varies enormously from flag to flag (Donaldson 1996; Mitroussi 2004; Winchester et al. 2006; Bloor and Sampson 2009). Special problems are observed with regard to training and qualifications requirements of seafarers. Concerns have been expressed not just about the quantity of seafarers but about their quality, too (Leggate 2004), especially with regard to fraudulent certificates and seagoing service testimonials (Obando-Rojas et al. 2001). Despite the need for highly qualified seafarers, fierce competition in the shipping markets has forced shipping lines to intensify cost control measures also in terms of labor. The pursuit of qualified labor at the lowest possible cost can generate negative side effects on training quality, particularly in developing countries (see e.g. Bloor and Sampson 2009).

\subsection{Social conditions and structures}

The internal organization of dock labor is taking place within a wider setting of social structures and conditions. As early as the 1960s, scholars argued that the longshore industry, because of its peculiar nature, should be considered as a separate labor market (Weinstein 1963). In contrast to more international and standardized organization structures in seafaring, a large variety in dock labor schemes can be observed. Ports can depend on a dock labor scheme based on a centrally managed pool of registered dock workers. The use of registered dockers through a pool can be mandatory or not. This obligation can be de facto or imposed by law. The dock worker pool schemes generally involve the designation of an "in-group" of officially registered (in effect, licensed) dock workers who are not permanently employed at particular stevedoring enterprises but hired through a central pool or hiring hall, which stevedores are obligated to use for their primary source of casual labor. The gang system (typically 
five to eight dockers per gang) is an important cornerstone in the organization and group structure of dock work.

There is a general trend toward open and autonomous pool systems with back-up of temporary employment agencies. In some cases, recent reforms have privatized the status and operation of these labor pools (e.g., in the Netherlands in 1995). In an increasing number of ports, dock workers are directly employed by terminal operators, instead of contracted via "pools".

Labor unions are typically very visible at the dock labor front, although again major differences in union power can be observed across seaports and countries (Turnbull and Wass 2006). Trade unions generally form a united front at the national level, the regional level, in the ports and at a port-company level. Social dialogue through effective bodies of joint consultation is considered as the key to a sustainable relation between port-related employers and trade unions (Turnbull 2006).

The seafarers' supply market is largely an agency-controlled labor market, excluding only coastal shipping (ILO 2001). Ship operators will at large contract the supply of onboard staff out to crew agencies or third party ship managers who, in turn, recruit appropriate labor through their local agents in developing countries and transitional states. Alternatively, shipping companies may wish to set up wholly or partly owned subsidiaries of crewing services in their preferred supply areas. Wages and terms and conditions of employment contracts are variably negotiated around the world. The International Transport Workers' Federation (ITF) is mostly concerned with making sure that seafarers are not placed on substandard vessels and are paid a minimum amount of wages. It can put pressure by boycotting operations of vessels which do not comply with the minimum standards, with the help of local affiliated transport federations. Labor unions in strong maritime nations still have a solid saying in employment negotiations and conditions, however, their significance in a highly competitive global seafarers' supply market is a diminishing one.

The work of ship operation for seafarers, much like that of the dock workers, is a "project type" of work by a small group of people, e.g., 15-25 people, being brought together and working closely together for a specific and limited time period. A very high rate of labor turnover contributes negatively to the aspect of socialization and work efficiency aboard vessels. In some sectors, such rate is estimated to be $75-100 \%$ every 18 months, a figure which is not to be found in any other industry (Robert and Moulin 2000). This is different from dock labor where "gangs" tend to be rather constant in composition over time, except in case of casual workers operating in a pool system. Ship managers can choose to man their vessels using a single national crew, a complement of two different nationalities or, more frequently nowadays, multinational crews. The manning of vessels increasingly from diverse countries requires careful consideration of issues of cultural convergence and conflict for effective and trouble-free ship operation. Social contact and most importantly effective communication aboard can be undermined by reduced manning, foreign language incompetency and potential incompatibility of cultures in multi-cultural crew complements. Ostreng (2001) describes the ship as a multi-ethnic and segregated social environment, where social contact and interactions among seafarers are rare and communicational problems are omnipresent (see also Theotokas and Progoulaki 2007). Shrinkage of crew sizes and tensions within the onboard community may result in reduced interaction in an already demanding physical and social environment. 
Both professions are facing an unequal gender balance. The dock labor workforce is characterized by a very low participation of women and a low multicultural mix. Women are also underrepresented in the much more multicultural seafaring profession - only about 1 or $2 \%$ of the 1.25 million seafarers in the world are women (Belcher et al. 2003). Prejudices, rigid attitudes, military-like structures in academies and aboard and discrimination have traditionally kept women largely outside the shipping industry. Institutional barriers have also existed (Giziakis et al. 2009). Thomas (2004a) suggests that there is strong evidence that gender stereotypes continue to exist in this male-dominated workplace, with women being denied promotion on the basis of their gender alone.

\subsection{Working conditions}

Dock work is generally considered as dangerous and tough, particularly when it involves the (un)lashing and securing of goods on board of ships or the handling between quay and yard or warehouse. While night work and weekend work are quite widespread, dock workers, who typically live in cities and villages close to the port area, only stay away from home for the duration of a shift. Double shifts are highly uncommon and are mostly not allowed due to the dangers linked to fatigue. Dockers working in the open air are exposed to a harsh environment linked to weather conditions, temperature differences between ship, quay, and warehouse, and the use of heavy equipment and cargoes.

Distinctive elements of shipboard life include isolation from friends and family, intermittent danger, boredom, forced contact with others, and inescapability of the environment (Helmreich et al. 1981). Such features can be found in work environments which are quite extreme and unique, like in Arctic and Antarctic stations (Gunderson 1996) and spacecraft (Helmreich et al. 1980) and are experienced differently by officers and ratings and perhaps to a greater degree today than in the 1950s and 1960s (Sampson and $\mathrm{Wu} 2003$ ), when longer stays in port and shorter distances from the cities resulted in less time and space compression for the seafarers. The job is of a highly technical nature and has been characterized by risk-due to the perils of the sea - and toughness - both in terms of the actual tasks involved and the environment of the job. Li and Wonham (2001) found that fatalities due to personal accidents on board ship constitute $90 \%$ of all mortality cases. Today, the severity of the profession and the stresses seafarers suffer has risen due to a series of hazards and risks, such as the risk of personal criminal liability in the case of sea pollution (e.g., with the European Union legislation) or the risk associated with increased piracy attacks. Cahoon and Haugstetter (2009) also suggest that the seafarer's job has become less challenging due to the impact of new technology, creating a feeling of job dissatisfaction and leading to resignation, increased costs for recruitment and loss of skills to other industries.

\section{Motivation of seafarers and dock workers}

Of paramount importance is that dock labor and seafarer arrangements seek motivation and work spirit. The literature review highlighted that motivation is linked to job satisfaction and has an impact on performance and labor productivity. A range of tools 
may motivate existing seafarers and dock workers and attract others to join these professions. These result from a critical analysis of the identified special features of the two sectors. Table 2 summarizes the main findings. The table is structured following a distinction between extrinsic motivators (e.g., remuneration which allows the individual to obtain outcomes of value) and intrinsic motivators (e.g., satisfaction which comes from the experience of successful activity performance) and combining the latter category with the job satisfaction features as identified by Warr (2002) and others (see literature review earlier).

\subsection{Extrinsic motivators}

Dock labor is characterized by specific remuneration systems which are often the result of a long history of social dialogue and conflicts. Traditional wage systems were based on time-rates or piece-rates. At present, a wide range of bonuses and miscellaneous compensations exist linked to the nature, complexity, and timeframe of the task. As a result, the base or guaranteed wage is often only a fraction of the monthly income a dock worker can generate. Wage levels and bonuses are also linked to the job category and or the job qualifications of the docker. Local employers' organizations are typically involved in specific training centers and associated examination procedures which allow dock workers to move up the ladder in terms of job categories or to obtain additional job qualifications.

The relatively high willingness of terminal operators to pay for dock work (sometimes even via non-registered bonuses) is explained by two key targets of terminal operators: (1) to meet market requirements by offering a high labor productivity, a high flexibility (which often comes at a high price) and continuous operations, and (2) to minimize the risk of "hidden costs" incurred by shortages of gangs or dock workers, cargo damage incidents, short isolated strikes and long port-wide strikes by dock workers with possibly detrimental effects on a port's reputation, accidents, and absenteeism. Hidden costs can also be the result of operational inefficiencies due to a lack of communication between the vessel and the stevedores, possible breakdowns of equipment or the late reception of the cargo or load plans.

In much the same way, the "hidden costs" of unmotivated crew can be high for a number of entities, including:

- The seafarers themselves (e.g., facing potential criminal charges, suffering injuries or even loss of life)

- The ship owner (e.g., facing potentially law suits, clean-up costs, higher insurance premiums, targeted inspections and port delays, etc.)

- Cargo interests (e.g., delayed/damaged cargo delivery)

- Wider communities (e.g., whose livelihood and economic situation can be seriously affected in the case of environmental disasters caused by major shipping accidents)

Traditionally, companies have relied on base pay schemes to remunerate their employees for their work input consistent with market conditions and in relation mostly to their credentials and length of service. Although for shore staff in shipping companies - and generally in shore industries - personnel cost in terms of salary is more or less a standardized expense established by national labor regulations and industrial 
Table 2 Extrinsic and intrinsic motivators

\begin{tabular}{|c|c|c|c|}
\hline Characteristics & Seafarers & Dock workers & (Dis)-Similarities \\
\hline \multicolumn{4}{|l|}{ Extrinsic motivators } \\
\hline Level of base wage & $\begin{array}{l}\text { Variable, depending on national } \\
\text { regulations - ITF basic wage } \\
\text { levels }\end{array}$ & $\begin{array}{l}\text { Generally in line with other } \\
\text { industries. }\end{array}$ & \\
\hline $\begin{array}{l}\text { Culture of formal bonuses and } \\
\text { additional pay }\end{array}$ & $\begin{array}{l}\text { Not really a formal culture - More } \\
\text { recently developed on a company- } \\
\text { basis }\end{array}$ & $\begin{array}{l}\text { Very common due to union power } \\
\text { (where applicable), specific } \\
\text { working conditions (weekend } \\
\text { work or night) and or compctition } \\
\text { between terminal operators to } \\
\text { attract best dock workers. }\end{array}$ & 7 \\
\hline $\begin{array}{l}\text { Culture of informal/non-registered } \\
\text { payments/bonuses }\end{array}$ & $\begin{array}{l}\text { Not really a formal culture - More } \\
\text { recently developed on a company- } \\
\text { basis }\end{array}$ & $\begin{array}{l}\text { In case of structural shortages of } \\
\text { dockers, terminal operators might } \\
\text { be inclined to make informal } \\
\text { payments. }\end{array}$ & \\
\hline $\begin{array}{l}\text { Mechanisms for obtaining wage } \\
\text { increases }\end{array}$ & $\begin{array}{l}\text { Number of years worked, job } \\
\text { qualifications or level of job } \\
\text { category. Labour unions often play } \\
\text { a key role in conditions of } \\
\text { collective agreements. }\end{array}$ & $\begin{array}{l}\text { Number of years worked, job } \\
\text { qualifications or level of job } \\
\text { category. Labour unions often play } \\
\text { a key role in conditions of } \\
\text { collective agreements. }\end{array}$ & \\
\hline Career advancement opportunities & $\begin{array}{l}\text { Sea-going experience essential for } \\
\text { further career advancement - } \\
\text { Also, shore opportunities }\end{array}$ & $\begin{array}{l}\text { Training programs, often } \\
\text { organized by employers' } \\
\text { organizations, allow to move up } \\
\text { the ladder in terms of 'job } \\
\text { categories' or to obtain additional } \\
\text { job qualifications'. }\end{array}$ & \\
\hline \multicolumn{4}{|l|}{ Intrinsic motivator's } \\
\hline $\begin{array}{l}\text { Relation between employee and } \\
\text { employer }\end{array}$ & $\begin{array}{l}\text { Variable depending on contract } \\
\text { (e.g. the seafarer as employee of } \\
\text { the manning agent/third party ship } \\
\text { manager, or of the ship operator) }\end{array}$ & Indirect in case of pool system. & \\
\hline Autonomy & $\begin{array}{l}\text { A great deal of every-day } \\
\text { autonomy but also strict regulatory } \\
\text { and management constraints. }\end{array}$ & $\begin{array}{l}\text { Gang is relevant unit. Relative } \\
\text { autonomy of gang to get the job } \\
\text { done. }\end{array}$ & \\
\hline Opportunity to utilize skills & $\begin{array}{l}\text { Dependent on job qualifications } \\
\text { and or job category of seafarer. } \\
\text { Lower level crew members } \\
\text { typically have less such } \\
\text { opportunities. }\end{array}$ & $\begin{array}{l}\text { Dependent on job qualifications } \\
\text { and or job category of the dock } \\
\text { worker. Lower class dock workers } \\
\text { are typically less motivated. }\end{array}$ & \\
\hline Externally generated goals & $\begin{array}{l}\text { Job and task demands typically are } \\
\text { well formulated. } \\
\text { Existence of striet regulatory } \\
\text { requirements about processes in } \\
\text { ship operation. }\end{array}$ & $\begin{array}{l}\text { Job and task demands typically are } \\
\text { well formulated. } \\
\text { Active vs. passive flexibility in } \\
\text { working hours and workload. } \\
\text { Older dockers often excluded from } \\
\text { 'heary' dock work. }\end{array}$ & \\
\hline Variety of tasks and skills & $\begin{array}{l}\text { Depending on job category - } \\
\text { Impact of high automation and } \\
\text { technology }\end{array}$ & $\begin{array}{l}\text { Relative 'freedom' for casual } \\
\text { workers vs. more repetitive work } \\
\text { for permanent workers. }\end{array}$ & \\
\hline Environmental clarity & $\begin{array}{l}\text { Job roles are typically well } \\
\text { formulatcd. } \\
\text { Feedback is not always adequate. } \\
\text { High tumover. }\end{array}$ & $\begin{array}{l}\text { Clarity of role, job security and } \\
\text { fcedback are strongly relatcd to } \\
\text { the dock labour system in place. }\end{array}$ & \\
\hline Physical security & $\begin{array}{l}\text { Harsh working conditions and } \\
\text { high accident rate can lead to } \\
\text { lower attractiveness and poor } \\
\text { image of profession. }\end{array}$ & $\begin{array}{l}\text { Harsh working conditions and } \\
\text { high accident rate can lead to } \\
\text { lower attractivencss and poor } \\
\text { image of profession. }\end{array}$ & \\
\hline $\begin{array}{l}\text { Supportive supervision effective } \\
\text { leadership }\end{array}$ & $\begin{array}{l}\text { Depending on the skills of the } \\
\text { Master onboard. }\end{array}$ & $\begin{array}{l}\text { Supervision mainly through gang } \\
\text { system. Also social control is } \\
\text { exerted by the gang structure. }\end{array}$ & $\neq$ \\
\hline $\begin{array}{l}\text { Opportunity for interpersonal } \\
\text { contact }\end{array}$ & $\begin{array}{l}\text { Closed social system onboard but } \\
\text { difficulties in communication and } \\
\text { interpersonal contact due to long } \\
\text { hours of work, reduced manning } \\
\text { levels and multi-culturalism. }\end{array}$ & $\begin{array}{l}\text { High in 'pool' system (through } \\
\text { labour union membership and } \\
\text { social role of hiring halls). Lower } \\
\text { in case of direct and permanent } \\
\text { employment with a specific } \\
\text { terminal operator. }\end{array}$ & $\neq$ \\
\hline Societal status of the profession & $\begin{array}{l}\text { An established societal status in } \\
\text { places with long shipping } \\
\text { tradition but generally regarded as } \\
\text { low-status and unappealing by the } \\
\text { wider public perception. }\end{array}$ & $\begin{array}{l}\text { Varies a lot from port to port: } \\
\text { ranges from 'overpaid and over- } \\
\text { unionized' to 'low level job' vs. } \\
\text { 'job proudness'. Seaports suffer } \\
\text { from a lack of public image or a } \\
\text { poor public image. }\end{array}$ & $=$ \\
\hline
\end{tabular}

green equality sign "very similar use or effect of the motivator for dock workers and seafarers"; red inequality sign "very different use or effect"; yellow solid line "somehow similar use or effect"

Source: own elaboration

custom, the case can be much different for seafarers. Non-national seafarers can be regarded as labor migrants but with their place of residence remaining in their home 
country and governed by terms and conditions of employment different from national seafarers. Great differences exist in pay rates among different nationality seafarers (ITF 2005).

While some shipping companies have adopted performance related pay schemes such as cash bonuses and employee stock ownership (V.Group 2006) it is not a common practice across the shipping industry. Rewarding performance with some form of contingent reimbursement means that employees will be motivated to strive toward high level of performance in anticipation for an enhanced level of remuneration. Managers in shipping companies, therefore, need to establish a correlation between the work performance of employees and their subsequent level of return. Both the forms of organizational performance to be assessed as well as the types of performance related remuneration should be clear and unambiguous. In terms of types of performance which will serve as the means of evaluation, ship managers can choose between a number, some of which are more suitable than others for seafarers:

- Financial performance - like company's profits, voyage results, freight earnings, capital growth or return on investment, loan attainment;

- Customer service - such as, success in charterers' vetting procedures, charterers' satisfaction, clientele base;

- Quality of service-for instance, number of cargo claims, demurrage/dispatch, insurance premiums/costs, $\mathrm{P}+\mathrm{I}$ claims;

- Efficiency and productivity - for example, number of days off-hire, operational costs, port turnaround times, PSC inspections, maintenance levels/repairs, accidents, crew injuries.

In the choice of the above, the ship manager's decision will of course be conditioned by whether the performance related remuneration scheme will apply to individual, group, department, or company performance and of course by the actual task characteristics of employees or departments involved.

Succession schemes for onboard posts could mean for seafarers opportunities for gaining a post in the company offices. This is perhaps one of the strongest incentives for seafarers, as such a development does not just have the symbolic value of a better status - it might not even have the monetary value of a better salary — but it is tied with a more practical and life-changing aspect, that of leading a professional life ashore rather at sea. While the prospect of a shore job might serve as strong extrinsic motivator to serve at sea for a period of time, it is typically not in the interest of shipping companies to promote seafarers from sea to shore jobs. Moreover, the ability and attractiveness of changing jobs from sea to land depend a lot on the balance of supply and demand in seafaring and in the land-based jobs market (see, e.g., Gardner et al. 2007).

\subsection{Intrinsic motivators}

Non-financial employment motivation and mental well-being can increase job satisfaction. In Table 2, we listed 10 features which are at the heart of job satisfaction. Some of these less obvious features are discussed in more detail in the following paragraphs.

The internationalization in the cargo handling industry (Notteboom 2002; Bichou and Bell 2007; Olivier et al. 2007; Notteboom and Rodrigue 2012) led to an increasing 
standardization of terminal equipment around the world. Still, productivity rates per container crane per shift differ across terminals given differences in motivation level and efficiency of dock worker gangs. The internationalization of cargo handling activities and advances in terminal management brought a decline of traditional patronage structures, making changes in employee-employer relations and the port labor system unavoidable.

Freedom and team spirit are generally highly valued by dockers. This might explain why many dockers, in contrast to employees in many other industries, feel comfortable in a situation where a direct relation between employer and employee is rather loose (in case of "pools" virtually absent).

For seafarers, the relation with their employers can be a varied one depending on the employment contract, that is, whether the seafarer is an employee of the manning agent/ third party ship manager, or of the ship operator. Loyalty and identification with the employer, for example, the manning agent, can be achieved through long-standing employment relations, but it will still not always mean identification with the ship seafarers are called to serve. The concept of instigating to their employees feelings of commitment to and loyalty in the company has been widespread in traditional ship owning firms. This is today much more difficult given the globalized sourcing of seafarers. A company may often build a dedicated pool of seafarers who regularly go on their ships. Companies may keep seafarers on their payroll, even for periods of time when the latter are not serving onboard the company's vessels, in order for them to retain the acquired expertise and be able to install more easily commitment, motivation and corporate culture.

To some extent, dock workers can rely on a certain level of autonomy in performing their tasks. This relative autonomy is to be situated at the level of the gang to which the individual dock worker belongs. The gang system in the port is often key to the motivation and productivity of the dock workers. Each gang is managed by a foreman and another person oversees several gangs working on the same ship. A competitive spirit between dock worker gangs and a strong social control within a gang enhance labor productivity per shift. A well-functioning gang system promotes a strong team player mentality and shows no mercy for dock workers who are not performing up to standard or highly value personal gains above the gang's achievements. Strong and highly motivated foremen typically create an atmosphere of coherence and a focus on strong team work.

The opportunity to utilize skills is strongly dependent on the job qualifications and or the job category of the dock worker. When dock workers are assigned to specific job categories then flexibility to utilize all skills is only guaranteed when a system of qualifications (based on certification or training) allows dock workers' mobility between categories. When dock workers strictly adhere to their specific professional category then the multi-skilled nature over the categories is typically low. A multiskilling orientation of dock workers classifications adds to job variety.

Training and a future career path are essential in achieving job satisfaction and a high productivity. To this end, many ports have a number of occupational categories of dock workers combined with clear rules regarding the flow from one category to another higher category.

Dock workers typically value flexibility in working hours. When the port labor system does not impose a work obligation at specific moments in time (for example for 
weekend work or work on holidays) finding enough volunteers is often a matter of providing generous extrinsic motivators (e.g., bonuses) for performing such tasks.

Like other industries, also dock labor is confronted with absenteeism. The reasons for absenteeism can be company-related (e.g., ineffective selection and placement procedures, excessive fatigue, ineffective use of skills, poor supervision, inadequate training or promotion programs, etc.) or personal causes (e.g., dual occupation, alcoholism or drugs). The power of absenteeism has been exercised many times by dock workers and associated labor unions. Thus, this problem can relate to job satisfaction, but it can also be an indicator of worker's responsibility in fulfilling contractual obligations.

Seafarers' job skills variety is dependent on job qualifications and/or job category of seafarer. For senior officers, typically a wide range of technical knowledge is required, such as cargo handling and loading/discharging operations, nautical and geographical understanding, but also good judgment, good communications skills with other crew but also external entities, good negotiation skills, e.g., when problems arise, such as events leading to potential claims. Lower level crew members typically have less such opportunities to utilize skills, as their tasks tend to be generally more of a routine type. Job and task demands typically are well formulated. This can be attributed foremost to the existence of strict regulatory requirements about processes in ship operation as well as the close intervention of the office with continuous monitoring of the ship's operation through advanced telecommunications.

As for autonomy, work related to ship operation has exhibited various degrees of autonomy through time - from when masters had the sole responsibility of the shipping business to when advanced technology and telecommunications brought the dominance of the office over the command and control of ship operation. Today, much more discussion has been going on about the value of empowerment of shipping personnel, the overriding authority of the Master, and the relationship between Master and Company. Empowerment, in line with the regulatory requirement of Chapter IX of the Safety of Life at Sea Convention, seems to fit quite well the model of service provision in shipping, where the main "production"/economic unit is far away from the management center, the shipping office. This is not always easily applicable or applied in shipping. This is due to a usually high turnover onboard vessels, which does not allow the building of strong, long-standing trust relationships, the capital intensity of the asset and of course availability of sophisticated information technology.

Feedback has constituted a regular practice of the ship operation business since advancements in telecommunications allowed the close watch of the ship by the office. With the introduction of the International Safety Management (ISM) Code, feedback, primarily in the form of spotting and recording non-conformities with established safety standards, has become mandatory by law. Apart from the obvious benefits of negative feedback, however, such as ability to apply corrective action, task feedback as a motivating factor should have an affirmative dimension, too. It can come both from the task itself, as well as from others. Implementation of appropriate information systems helps the process and practice of feedback.

The degree of investment in training and development for their seafarers varies among companies. Extensive outsourcing of human resource functions for seafarers and the use of crew agencies means that a systematic approach to the management of training may not be a choice or an easy target for companies. A ship-operating company which mans its vessels on an ad hoc, "as needed" basis from crewing 
agencies around the world and with a high turnover will find it quite difficult, for example, to engage in any objective assessment of training needs. This requires analysis at three distinct levels, the organization, the task and the person, and at high turnovers and with minimum knowledge of the employees the chain of the assessment is broken at the third tier of the analysis. In the same way, the review and evaluation of training programs can hardly be effectively carried out when seafarers do not stay with the same company for more than 6-8 months.

The societal status of the profession and professional pride of the dock worker differs a lot from port to port which serves as an example of the role of cultural differences in relation to the social position of a specific job. In some ports, job loyalty, and pride are high. In other ports, dock work is being regarded as a very low-status job and perceived of a temporary nature. The public perception on dock workers can range from "overpaid and over-unionized" to "low level job". The dock worker profession is only visible to the general public in cases of accidents or strikes, which add to the possible negative connotation of the profession.

While in some parts of the world merchant marine officers still enjoy an acceptable form of social prestige, in most parts of the world the seafaring profession suffers from a poor image. The acknowledgment of the task significance for crew member begins at the industry level. The shipping industry has long lost its appeal to the wider public as an attractive career field for a number of reasons. As one's own perception of their job, however, is largely formed by how others seem to perceive it, seafarers, need firstly an "industry image injection" to enhance their task significance perception. At a different level, each individual should be made to feel important for the organization with regard to the work he or she offers to it. Such recognition of the significance of the work undertaken should be effectively communicated to each person in question and to others within the organization. Formal acknowledgement on the part of employees of their job description, as required by the ISM Code, is one such instance. But other practices, like participation in safety assessments as well as verbal encouragement from line managers should also be implemented.

An especially significant aspect of work for seafarers is the closed social system onboard and the difficulties in communication and interpersonal contact due to long hours of work, reduced manning levels and multi-culturalism onboard vessels. The concept of work/life balance is by definition almost non-existent during the time of onboard employment but there are ways to improve it. For example, the proper application of international safety standards and standards relating to rest hours and other-namely the Standards of Training, Certification and Watchkeeping 1995 (STCW 1995) - should be ensured. Strategies which can be adopted to establish a balance in seafarers' work and life include (Thomas et al. 2003):

- Shorter trips (preferably no longer than 4 months)

- Paid leave of a comparable duration to sea-time

- Continuous employment rather than employment by voyage

- Training time to be added on to leave period

- Opportunities for partners (and where possible for children) to sail

- Improved access to cheaper communication, for example, helping with the purchase of household communication equipment (faxes, computers, etc.) or providing subsidized phone cards and access to email facilities for those onboard 
- Increased contact between seafarers' partners and seafarers' employers

- Opportunities for seafarers' families to make contact with each other

Thomas (2004b) also identifies the need on the part of the companies to develop welfare support structures, such as access to free confidential counseling services to help seafarers deal with traumatic experiences - violent or fatal injuries, colleague's suicides, potentially life threatening events related to their safety or security - the latter are exposed to more often than perhaps assumed. The same type of welfare support structures are important in a dock labor context.

\section{Discussion and conclusion}

The contexts and constituents of the professions of dock worker and seafarer in many aspects differ from more traditional professions in economic life. We argue that the distinctive nature of the working environment on ships and at cargo handling facilities in seaports not only leads to specific job characteristics, but also requires a tailor-made approach to the motivation of seafarers and dock workers and to motivate others to join these professions. This need for a customization of motivation tools is particularly felt at the level of:

- The relationship between employee and employer: the working conditions and arrangements have made that dock workers and seafarers are performing their job in an environment of weak direct interaction with the employer. Dock workers highly value freedom in choosing a task or even a terminal. This desire for "freedom of choice" is at the core of the typical casual labor arrangements found in dock labor pools. Instead of establishing a direct relation between employee and employer, these pools avoid a long-term and unilateral dependency of a dock worker on a specific terminal operator. In combination with union membership, the social dimension of hiring halls and the role of gangs, pools thus strengthen a feeling of autonomy and freedom among dock workers. A lack of long-term dependency of seafarers on specific ship operators is also true nowadays. But for seafarers, the development of primarily indirect relations between employer and employees and of mostly short-term and ad-hoc employment contracts is attributed to the fragmentation of the shipping industry and a globalized crew sourcing in search of the most cost-effective employment, rather than a desire of "freedom of choice" on the seafarers' part. The feeling of autonomy is further enhanced by the rather isolated nature of the work place (i.e., a ship at sea) and the dominant role of the ship's captain in such an environment;

- Remuneration: dock workers are generally paid well not only to motivate to be highly productive or flexible, but also to make sure that they show a high level of responsibility to avoid "hidden costs". The unique skills required a lack of mobility of dock workers between ports and the risks associated with the profession make that high remuneration claims are likely to subsist. Remuneration for seafarers tends to generally reflect the high-risk nature and inherent difficulties of the job. However, pay discrepancies between nationalities onboard vessels, competitive compensation schemes in jobs ashore and the practically non-existent work/life balance 
for seafarers during the time of service onboard create additional complications for their motivation;

- Societal status of the profession: as the maritime industry suffers from a lack of a public image or a poor public image, motivation tools should not only be directed to existing seafarers and dock workers, but also to possible future candidates for such a profession. In line with the "soft values" approach introduced by Van Hooydonk (2007), the port and maritime industry is challenged to improve its public image. Actions in this field are expected to have positive effects on the societal status of the profession, the professional pride of dock workers and seafarers, and the visibility and attractiveness of these maritime-related professions.

- Working conditions: the seafaring profession is a high-risk profession due to perils of the sea, piracy, adverse weather conditions, use of heavy equipment, long hours of work, fatigue, irregular meals, psychological stress, intermittent danger, boredom, forced contact with others and inescapability of the environment. Added to the above, the shrinkage of manning levels, the multicultural composition of crew and the high turnover of seafarers onboard pose special complications for motivation, for effective cooperation, task coordination and job performance. Dock workers are also subject to harsh working conditions, but in general the social conditions are far less extreme and strongly defined by the characteristics of the local dock labor system. The job motivation level of a dock worker is influenced by the "fit" between personal character and the specific configuration of the local dock labor environment, e.g. in terms of social control by the "gang" or labor union;

- Work/life balance: seafarers suffer from isolation from friends and family for long periods of time as their place of work is also their place of living. Traditional motivation schemes to enhance the work/life balance, such as flexible working time, telecommuting, or job sharing are inappropriate for shipboard life. Such idiosyncrasies of ship-based jobs make it imperative for ship managers to embrace a more open and at the same time more case-specific approach to crew motivation especially when it comes to home-work interface.

The specific industry contexts in seafaring and dock labor instigate a mix of motivation processes tools that is distinct from other industries. We therefore propose the addition of a contextual layer to the study of motivation at work. Although key motivation principles, such as pay rewards can be used as universally applicable, several strands of the industry and job layers necessitate consideration of contextspecific parameters which affect the ways people can be motivated. This is very much evident from the differences as much as the similarities of the job characteristics of the two chosen shipping professions, dock workers and seafarers.

The contribution of this paper to theory and practice is diverse. First, it adds to the conceptualization of motivation by contextualizing it in the specific setting of male dominated professions and of work environments characterized by the formation of highly interdependent, mostly disjointed and primarily contractually fragmented teams. Extant work on motivation has been done in a limited range of industrial and occupational sectors and so this paper contributes to its critical evaluation in a new context.

Second, the above-mentioned parameters point to a unique business environment for the application of motivation principles, as they may act as motivation moderators for employees in the seafaring and dock work, as well as for any other personnel in 
industries with corresponding characteristics. Such business environment varies to that dealt with by the extensive literature on work motivation and so the present study adds to the latter a new important dimension.

Third, the paper also makes a distinct contribution to shipping-specific literature, which essentially lacks any discussion on motivation, especially of dock workers, or any critical comparison of employment constituents of its two main working centers, the ship and the port.

Fourth, consideration of the seafaring and dock labor employment components within the realms of motivation can provide a useful tool for practitioners wishing to instigate effective and sector-specific motivation policies and processes.

The paper may suggest several avenues for future research. This examination is mainly conceptual and explorative and future research could benefit from engaging in a further empirical examination through collection of relevant data from either or both dock workers and seafarers. We believe this paper offers a very sound foundation for further empirical research. Such investigations can take a cross-sectional view or longitudinal investigations could be undertaken to look at how dock workers and seafarers' motivation changes over time in response to changes in their life and careers. Also, cross-industrial research projects may also be conducted to underline particularly the impact of context in motivation.

\section{References}

Adams JC (1963) Towards an understanding of inequity. J Abnorm Soc Psychol 67(5):422-436

Adams JS (1965) Inequity in social exchange. In: Berkowitz L (ed) Advances in experimental social psychology. Academic, New York

Alderfer CP (1972) Existence, relatedness and growth. Collier Macmillan, New York

Allen RS, Helms MM (2002) Employee perceptions of the relationship between strategy, rewards and organizational performance. J Bus Strateg 19(2):115-139

Belcher P, Sampson H, Thomas M, Veiga J, Zhao M (2003) Women seafarers: global employment policies and practices. International Labour Office, Geneva

Bichou K, Bell M (2007) Internationalisation and consolidation of the container port industry: assessment of channel structure and relationships. Marit Econ Logist 9:35-51

Bloor M, Sampson H (2009) Regulatory enforcement of labour standards in an outsourcing industry: the case of the shipping industry. Work Employ Soc 23:711-726

Bolle F (2006) The ILO's new Convention on maritime labour: an innovative instrument. Int Labour Rev 145(1-2):135-142

Cahoon S, Haugstetter (2009) Shipping, shortages and generation Y. http://www.he-alert.org/documents/ published/he00760.pdf. Accessed 1 Nov 2009

Deci EL, Ryan RM (1985) Intrinsic motivation and self-determination in human behavior. Plenum, New York

Delaney JT, Huselid MA (1996) The impact of human resource management practices on perceptions of organizational performance. Acad Manag J 39(4):949-969

Donaldson L (1996) Safer ships, cleaner seas - a reflection on progress. Warsash Maritime Centre, Southampton

Fernandez-Araoz C (1999) Hiring without firing. Harv Bus Rev : 109-118

Gardner BM, Marlow PB, Naim MM, Nair R, Pettit SJ (2007) The policy implications of market failure for the land-based jobs market for British seafarers. Mar Policy 31(2):117-124

Giziakis C, Miliaraki M, Lema E (2009) Survey on the discrimination towards female seafarers in Greece as a marine cultured country. Conference Proceedings, Annual Conference of the International Association of Maritime Economists. Copenhagen 24-26 June 2009

Grugulis I, Bevitt S (2002) The impact of investors in people: a case study of a hospital trust. Hum Resour Manag J 12(3):44-60

Gunderson EKE (1996) Adaptation to extreme environments: prediction of performance. Report \#66-17, Navy Neuropsychiatric Research Unit, San Diego 
Guo JL, Liang GS, Ye KD (2006) An influence model in seafaring choice for Taiwan navigation students. Marit Policy Manag 33(4):403-421

Hackman JR, Oldham GR (1976) Motivation through the design of work: test of a theory. Organ Behav Hum Perform 16:250-279

Hackman RJ, Oldham GR (1980) Work redesign. Addison-Wesley, London

Helmreich RL, Wilhelm JA, Runge TE (1980) Psychological considerations in future space missions. In: Chester S, Winter D (eds) The human factors of outer space production. American Association for the Advancement of Science, Washington, DC

Helmreich RL, Wilhelm JA, Runge TE (1981) Motivation, organization and satisfaction aboard ship. Conference Proceedings, The 7th Annual Maritime Industry Symposium, California Maritime Academy, Vallejo, California, 19 May

Herzberg F, Mausner B, Snyderman B (1959) Motivation to work. Wiley, New York

Horwitz FM, Heng CT, Quazi HA (2003) Finders, keepers? Attracting, motivating and retaining knowledge workers. Hum Resour Manag J 13(4):23-44

Hume DA (1995) Reward management. Employee performance, motivation and pay. Blackwell, Oxford

Huselid MA, Jackson SE, Schuler RS (1997) Technical and strategic human resource management effectiveness as determinants of firm performance. Acad Manag J 40(1):171-188

International Labour Organization (2001) The impact on seafarers' living and working conditions of changes in the structure of the shipping industry. Report for discussion at the 29th session of the Joint Maritime Commission, JMC/29/2001/3, International Labour Office, Geneva. http://www.ilo.org/public/english/ dialogue/sector/techmeet/jmc01/jmc-r3.pdf. Accessed 16 Jun 2010

International Maritime Organisation (2009) Go to sea: a campaign to attract entrants to the shipping industry. http:/www.imo.org/includes/blastDataOnly.asp/data_id\%3D23804/Gotosea!campaigndocument.pdf. Accessed 28 Oct 2009

International Transport Workers' Federation (2005) The ITF flag of convenience campaign. ITF Seafarers' Bulletin, Issue 1

Josephson M, Heijbe B, Voss M, Alfredsson L, Vingard E (2008) Influence of self-reported work conditions and health on full, partial and no return to work after long-term sickness absence. Scand J Work Environ Health 34(6):430

Kokoszko N, Cahoon S (2007) Developing employer of choice potential in the shipping industry: an organizational perspective. Conference Proceedings, 2007 Annual Conference of the International Association of Maritime Economists, Athens, 4-6 July

Labriola M, Lund T, Christensen KB, Kristensen TS (2006) Multilevel analysis of individual and contextual factors as predictors of return to work. J Occup Environ Med 48(11):1181-1188

Lawler E (2000) Rewarding excellence: pay strategies for the new economy. Jossey Bass, New York

Leggate H (2004) The future shortage of seafarers: will it become a reality? Marit Policy Manag 31(1):3-13

Li KX, Wonham J (2001) Maritime legislation: new areas for safety of life at sea. Marit Policy Manag 28(3): $225-234$

Locke EA (1968) Toward a theory of task motivation and incentives. Organ Behav Hum Perform 3:157-189

Maslow AH (1954) Motivation and personality. Harper \& Row, New York

McClelland DC (1962) Business drive and national achievement. Harv Bus Rev 40:99-112

McClelland DC, Winter DG (1969) Motivating economic achievement. Free Press, New York

McConville J, Glen D (1997) The employment implications of the United Kingdom's merchant fleet's decline. Mar Policy 21(3):267-276

McGregor DC (1960) The human side of enterprise. McGraw-Hill, New York

Miao CF, Evans KR, Zou S (2007) The role of salesperson motivation in sales control systems - intrinsic and extrinsic motivation revisited. J Bus Res 60:417-425

Miner JB, Smith NR, Bracker JS (1994) Role of entrepreneurial task motivation in the growth of technologically innovative firms: interpretations from follow-up data. J Appl Psychol 79:627-630

Mitroussi K (2004) Quality in shipping: IMO's role and problems of implementation. Disaster Prev Manag 13(1):50-58

Mitroussi K, Chang C (2008) An appraisal of motivation principles in shipping companies. Conference Proceedings, International Forum on Shipping, Ports and Airports 2008, Hong Kong, 25-28 May 2008

Murphy WH (2004) 2In pursuit of short-term goals: anticipating the unintended consequences of using special incentives to motivate the sales force. J Bus Res 57:1265-1275

Notteboom T (2002) Consolidation and contestability in the European container handling industry. Marit Policy Manag 29(3):257-269

Notteboom T, Rodrigue J-P (2012) The corporate geography of global container terminal operators. Marit Policy Manag 39(3):249-279 
Obando-Rojas B, Badigannavar V, Lane T, Bloor M, Maguire M (2001) A study on fraudulent practices associated with certificates of competency and endorsements. Main Report. Report commissioned by the International Maritime Organization (IMO), Pub 483/01. http://www.imo.org/includes/blast_bindoc.asp? doc $\mathrm{id}=1128 \&$ format $=$ PDF. Accessed 22 Jul 2010

Olivier D, Parola F, Slack B, Wang J (2007) The time scale of internationalisation: the case of the container port industry. Marit Econ Logist 9:1-34

Ortega A, Christensen KB, Hogh A, Rugulies R, Borg V (2011) One-year prospective study on the effect of workplace bullying on long-term sickness absence. J Nurs Manag 19(6):752-759

Ostreng D (2001) Does togetherness make friends? Stereotypes and intergroup contact on multiethnic-crewed ships. Tønsberg: Vestfold College Publication Series/Paper 2.

Pettit SJ, Gardner BM, Marlow PB, Naim MM, Nair R (2005) Ex-seafarers shore-based employment: the current UK situation. Mar Policy 29:521-531

Pfeffer J (1995) Producing sustainable competitive advantage through the effective management of people. Acad Manag Exec 9(1):55-72

Piniella F, Silos JM, Bernal F (2013) Who will give effect to the ILO's Maritime Labour Convention, 2006? Int Labour Rev 152(1):59-83

Robert NR, Moulin R (2000). Issues related to recruiting, training and retaining seafarers'. Conference Proceedings. Maritime Careers Conference: creating an action plan for recruiting and retaining American mariners. United States Merchant Marine Academy, 23-24 September

Rose T, Manley K (2010) Motivation toward financial incentive goals on construction projects. J Bus Res. doi: 10.1016/j.jbusres.2010.07.003

Sampson H, Wu B (2003) Compressing time and constraining space: the contradictory effect of ICT and containerization on international shipping labour. Int Rev Soc Hist 48:123-152

Simpson WA (1983) Motivation. A manager's guide. The Industrial Society, London

Thakor MV, Joshi AW (2005) Motivating salesperson customer orientation: insights from the job characteristics model. J Bus Res 58:584-592

Theotokas I, Progoulaki M (2007) Cultural diversity, manning strategies and management practices in Greek shipping. Marit Policy Manag 34(4):383-403

Thomas M (2004a) 'Get yourself a proper job girlie!': recruitment, retention and women seafarers. Marit Policy Manag 31(4):309-318

Thomas M (2004b) All in a day's work for seafarers?. The Sea

Thomas M, Sampson H, Zhao M (2003) Finding a balance: companies, seafarers and family life. Marit Policy Manag 30(1):59-76

Turnbull P (2006) Social dialogue in the process of structural adjustment and private sector participation in ports: a practical guidance manual. International Labour Organization (ILO), Geneva

Turnbull P, Wass VJ (2006) Defending Dock Workers - Globalization and labor relations in the world's ports. Proceedings of the 20th Conference of the Association of Industrial Relations Academics of Australia and New Zealand, pp. 519-532

V.Group (2006) Making things happen. Annual review 2006. http://www.vships.com. Accessed 7 Jul 2008

Van Hooydonk E (2007) Soft values of seaports: a strategy for the restoration of public support for seaports. Garant, Antwerp

Vroom VH (1964) Work and motivation. Wiley, New York

Warr PB (2002), The study of well-being, behaviour and attitudes, in ed PB Warr, Psychology at Work, London: Penguin Books

Weinstein P (1963) The featherbedding problem. IRRA Proceedings of 16th annual Meeting

Winchester N, Sampson H, Shelly T (2006) An analysis of crewing levels: findings from the SIRC global labour market survey. SIRC, Cardiff

Wong CS, Hiu C, Law KS (1998) Longitudinal study of the job perception-job satisfaction relationship: a test of the three alternative specifications. J Occup Organ Psychol 71:127-146

Wu B, Morris J (2006) 'A life on the ocean wave': the 'post-socialist' careers of Chinese, Russian and Eastern European seafarers. Int J Hum Resour Manag 17(1):25-48

Wu B, Sampson H (2005) Reconsidering the cargo sector's seafarer labor market: a 21st century profile of global seafarers. Ocean Yearb 19:357-380, University of Chicago, Chicago

Zinkhan GM, Hong JW, Lawson R (1990) Achievement and affiliation motivation. Changing patterns in social values as represented in American advertising. J Bus Res 20:135-143 